\title{
PENGEMBANGAN BAHAN AJAR IPS BERBASIS KERAGAMAN BUDAYA BATIK JENOGOROAN UNTUK MENINGKATKAN BERPIKIR KRITIS SISWA
}

\author{
Siti Nurul Hidayah \\ Prodi Tadris IPS, Fakultas Tarbiyah, Institut Ilmu Keislaman Zainul Hasan (INZAH) \\ nurulhidayah804@gmail.com
}

\begin{abstract}
Abstrak
Penelitian ini bertujuan untuk meningkatkan berpikir kritis melalui pengembangan bahan ajar IPS berbasis keragaman budaya batik jenogoroan pada siswa kelas VII di SMPN 2 Bojonegoro. Penelitian ini dilaksanakan dalam 3 tahap mengikuti rancangan Borg and Gall, yaitu tahap studi pendahuluan, tahap merancang produk bahan ajar berbentuk modul, dan dilanjutkan dengan tahap uji coba atau tahap pelaksanaan pembelajaran di kelas menggunakan rancangan one group pretest-posttest design. Data dari hasil penelitian yang diperoleh sebagai berikut: (1) kelayakan modul berbasis keragaman budaya batik jenogoroan layak digunakan melalui 3 uji validasi ahli, kelayakan modul dilihat dari 3 komponen yaitu isi, penyajian, dan kebahasaan. Hasil validasi dari ketiga validator yaitu: skor rata-rata komponen isi 3,53, komponen kebahasaan 3,40 , dan komponen penyajian 3,55. Ketiga skor tersebut menunjukkan kategori baik/layak yang artinya modul berbasis keragaman budaya batik jenogoroan dapat digunakan dengan sedikit revisi. (2) efektivitas modul berbasis keragaman budaya batik jenogoroan dapat meningkatkan berpikir kritis siswa dapat dilihat dari hasil test antara pre test dan post test, hasil tersebut menunjukkan bahwa skor rata-rata pre test $72,13 \%$, sedangkan skor rata-rata post test $80,35 \%$. Hasil pre test menuju post tets mengalami peningkatan 8,22 . Berdasarkan hasil analisis data, dapat disimpulkan bahwa bahan ajar berbasis keragaman budaya batik jenogoroan efektif dapat meningkatkan berpikir kritis siswa kelas VII pada mata pelajaran IPS khususnya pada materi keragaman budaya jika dilihat dari hasil test yang mengalami peningkatan.
\end{abstract}

Kata Kunci: Bahan Ajar, Keragaman Budaya, Batik Jenogoroan, Berpikir Kritis

\begin{abstract}
This study aims to improve critical thinking through the development of social sciences teaching material toward cultural diversity batik jenogoroan in students class VII SMPN 2 Bojonegoro. The research was conducted in three stages following the draft Borg and Gall, that is the preliminary studies aimed, the stage of product designing teaching materials students with the module, and continued with the testing stage or stages of implementation in the classroom design was one group pretest-posttest design. Data from the research results obtained as follows: (1) the feasibility of module based cultural diversity batik jenogoroan worthy used through 3 expert validation test, the feasibility of module seen from three components: content, presentation, and language. The results of the validation of third validator namely: the average score of the content component 3.53, 3.40 linguistic components, and presentation components of 3.55. All three scores indicate good category/feasible, which means module based cultural diversity-based batik jenogoroan can be used with minimal revision. (2) the effectiveness of module toward cultural diversity batik jenogoroan can enhance students' critical thinking can be seen from the test results between the pre-test and post-test, the results showed that the average score pre test $72.13 \%$, while the average score of post test $80.35 \%$. The results of the pre-test to post-tets increased 8.22. Based on the analysis, it can be concluded that based teaching materials cultural diversity batik jenogoroan can effectively improve critical thinking students' VII classes in social studies, especially on the matter of cultural diversity when seen from the test results that have increased.
\end{abstract}

Keywords: Teaching Materials, Cultural Diversity, Batik Jenogoroan, Critical Thinking

\section{PENDAHULUAN}

Pada penerapan kurikulum 2013 dalam pembelajaran guru dituntut tidak hanya sekedar menyampaikan materi kepada siswa namun guru juga harus mengajarkan siswa untuk berpikir. Tiap pengetahuan 
yang diajarkan, pembelajarannya harus sampai membuat siswa terampil dalam menyajikan pengetahuan yang dikuasainya secara konkrit dan abstrak.

Pada kurikulum 2013 tujuan yang ingin dicapai bukan hanya terpaku pada hasil akhir tetapi proses dalam pembelajaran tersebut dapat meningkatkan kemampuan berpikir kritis siswa, sehingga akan menghasilkan siswa yang mempunyai bekal dalam menghadapi masa depan.

Kemampuan berpikir kritis sangat penting bagi siswa karena merupakan esensi dari dimensi belajar dan berkaitan dengan kehidupan masa depan siswa. Sedangkan proses pembelajaran saat ini masih belum mampu meningkatkan kemampuan berpikir kritis siswa.

Dikarenakan proses pembelajaran saat ini masih mencapai tujuan pembelajaran tingkat rendah yaitu hanya mengetahui, memahami, dan menggunakan belum mampu menumbuhkan kebiasaan berpikir kritis dalam pembelajarannya.

Proses pembelajaran saat ini sebagian besar masih berupa kegiatan belajar berupa menambah pengetahuan, yaitu kegiatan menghadiri, mendengar dan mencatat penjelasan dari guru. Pembelajaran saat ini masih diimplementasikan pada tataran mentrasfer, menyampaikan pengetahuan guru kepada siswa.

Bagi siswa yang pasif hanya akan menerima apa saja yang disampaikan oleh guru tanpa mempunyai kesempatan untuk membagun sendiri pengetahuan yang dibutuhkan dan diminatinya. Sedangkan dalam proses belajar siswa harus terlibat aktif dan siswa menjadi pusat kegiatan belajar dan pembelajaran di kelas. Sedangkan guru memfasilitasi proses dengan mengajar menggunakan cara-cara yang menarik (Esa, 2009:116). Siswa dalam pembelajaran harus aktif dalam mencari pengetahuannya sendiri yang mana sesuai dengan konsep kurikulum 2013 di atas, di dalam pembelajaran IPS secara utuh harus dapat meningkatkan kompetensi yang dimiliki siswa.

Sedangkan masalahnya dalam pembelajaran IPS yang sering kita temukan di kelas saat ini masih belum mampu menumbuhkan kemampuan berpikir kritis dalam diri siswa. Karena IPS dianggap sebagai pembelajaran yang membosankan.

Banyak penyebab yang melatar belakangi permasalahannya, salah satunya menurut penelitian yang dilakukan oleh Soemantri (2002), yang mana hasil penelitian menunjukkan bahwa pembelajaran IPS sangat menjemukan karena penyajiannya bersifat monoton dan eksponsitoris sehingga siswa kurang antusias dan berakibat pembelajaran menjadi kurang menarik. Siswa hanya menjadi pihak yang pasif menerima apa yang disampaikan oleh guru, sedangkan guru menjadi pihak yang aktif.

Adanya hal tersebutkan mengakibatkan potensi yang ada pada siswa tidak tumbuh dengan baik, sehingga kemampuan berpikir kritis siswa tidak meningkat. Untuk meningkatkannya perlu dilakukan pembelajaran yang interaktif, menarik minat siswa sehingga dapat mengembangkan potensi yang mereka miliki.

Sementara itu pendidikan di Indonesia khususnya di SMPN 2 Bojonegoro yang merupakan salah satu sekolah yang menerapkan kurikulum 2013 dalam pembelajarannya. Sekolah tersebut masih mempunyai permasalah yaitu kurang meningkatkannya high other thingking (berpikir tingkat tinggi di dalam pembelajarannya. Kemampuan siswa dalam pembelajaran IPS masih di bawah rata-rata, Kendala tersebut dikarenakan dominannya peran guru dalam pembelajaran, siswa hanya dianggap sebagai tempat trasfer ilmu oleh guru.

Selain itu di dalam pembelajaran sumber belajar hanya menggunakan buku pegangan guru dan siswa, sedangkan di dalam kelas masih belum tersedia LCD untuk menunjang kegiatan pembelajaran. Adanya kendala tersebut membuat siswa menjadi pasif dalam pembelajaran. Jika hanya guru yang memberikan pengetahuan, sedangkan siswa hanya mendengarkan penjelasan guru, tanpa mencari pengetahuannya sendiri, akan sulit untuk menumbuhkan kemampuan berpikir kritis siswa.

Keadaan di atas menunjukkan bahwa guru harus membantu siswa untuk 
membangun pengetahuannya, diperlukan sarana pembelajaran yang efektif untuk dapat menumbuhkan minat siswa sehingga dapat meningkatkan kemampuan berpikir kritis.

Salah satu sarana belajar yang efektif dalam pembelajaran yaitu membutuhkan bahan ajar seperti modul yang inovatif, variatif, menarik, dan sesuai dengan kebutuhan siswa. Akan tetapi pendidikan dalam negeri khususnya di SMPN 2 Bojonegoro masih jarang dilakukan.

Sehingga dalam pendidikan guru berperan penting untuk mengembangkan bahan ajar yang menarik di dalam kelas, sehingga dapat meningkatkan minat siswa dalam pembelajaran di kelas untuk dapat meningkatkan berpikir kritis (Pannen, I aulina, 2001:6). Sedangkan buku pelajaran yang ada di sekolah-sekolah jika ditinjau dari jumlah, jenis, maupun kualitasnya sangat bervairiasi, sementara buku siswa digunakan sebagai buku rujukan utama dalam proses pembelajaran.

Permasalahannya guru seringkali tidak merujuk kurikulum dalam perencanaan dan implementasi pembelajarannya, tetapi merujuk pada buku siswa yang digunakan. Dengan demikian, buku siswa atau buku ajar harus disusun sebaik mungkin kaitannya dengan konsep agar menjadi sumber pencerdasan siswa.

Peneliti memilih mengembangkan bahan ajar berupa modul karena buku pegangan siswa yang digunakan pada saat ini minim materi, jika dilihat dari kedalaman pengetahuannya, sehingga siswa sedikit memperoleh pegetahuan. Sehingga peneliti mengembangkan modul untuk memudahkan siswa dalam pembelajaran, juga untuk mengembangkan materi yang lebih luas dan menarik minat belajar siswa.

Selain itu modul juga merupakan bentuk bahan ajar yang dapat membantu siswa belajar sendiri untuk memperoleh pengetahuan-pengetahuan berdasarkan pengalaman belajar mandiri sehingga dapat meningkatkan kemampuan berpikir mereka dalam mengaitkan apa yang mereka pelajari.

Modul diarahkan agar siswa lebih aktif dalam mengikuti proses pembelajaran melalui kegiatan mengamati, menanya, mencoba, menalar, berdiskusi serta untuk meningkatkan kemampuan berkomunikasi siswa secara aktif (Mulyasa, 2008:43). Sehingga modul yang digunakan harus dapat menarik minat siswa dalam pembelajaran.

Alasan di atas salah satu yang melatarbelakangi penelitian ini bahwa dalam pembelajaran IPS dibutuhkan bahan ajar dalam bentuk modul yang lebih komplek dibandingkan dengan buku siswa yang telah tersedia, sehingga dapat menarik minat siswa dalam belajar.

Untuk menumbuhkan minat siswa dalam pembelajaran dibutuhkan pengembangan modul yang tidak hanya memberikan pengetahuan kepada siswa tetapi dapat meningkatkan berpikir kritis siswa. Sedangkan salah satu bahan pembelajaran yang menarik yang dapat menumbuhkan potensi dalam diri siswa adalah dengan memperhatikan keanekaragaman lingkungan sosial budaya yang ada disekitar siswa untuk dijadikan bahan ajar yang inovatif (Trianto. 2011:103).

Budaya termasuk dalam permasalahan yang cukup menghawatirkan dalam pembelajaran IPS pada saat ini dikarenakan generasi muda bangsa Indonesia berada pada tingkat kemunduran. Banyak generasi muda yang tidak mengenal budaya bangsanya bahkan budaya daerahnya, sehingga mengakibatkan siswa kurang memiliki nilai-nilai kearifan dari budaya tersebut.

Padahal dalam pembelajaran IPS lingkungan sosial sangat penting bagi pembelajaran, seperti yang dikemukakan oleh Jean Piaget dan Vygostky yang menekankan bahwa pentingnya lingkungan sosial dalam belajar dengan menyatakan bahwa integrasi kemampuan dalam belajar kelompok akan dapat meningkat pengubahan secara konseptual (Baharuddin., Wahyuni Nur Esa, 2009:117). Anak harus membangun sendiri skemata-skemata dari pengalaman sendiri dengan lingkungannya (Ahmadi, Khoiru, I., Amri, S, 2011: 49).

Penelitian ini tentang batik jenogoroan yang merupakan salah satu keanekaragaman budaya yang dapat 
digunakan sebagai bahan ajar siswa karena pada saat ini banyaknya generasi muda yang tidak lagi mengenal batik yang dihasilkan daerahnya.

Padahal di dalam batik mengandung nilai-nilai kearifan dan hal-hal menarik yang bisa menjadi penguat ketahanan budaya bagi siswa, dengan mempelajari batik beserta nilai-nilai yang terkandung di dalamnya akan meningkatkan berfikir kritis siswa.

Sedangkan dalam mata pelajaran IPS dapat memuat nilai-nilai batik agar penanaman budaya lokal bisa kembali menguat dikalangan siswa. Karena itu batik perlu diintegrasikan ke dalam proses pembelajaran IPS, dengan memasukkan materi itu sebagai bahan pembelajaran yang akan membuat proses belajar menjadi menyenangkan dan menarik minat siswa.

Selain untuk menciptakan pembelajaran yang menarik peneliti juga ingin meningkatkan berpikir kritis dalam diri siswa. Ada beberapa contoh penelitian terdahulu yang telah melakukan penelitian tentang kebudayaan yang digunakan sebagai bahan ajar dalam pembelajaran.

Penelitian ini bertujuan untuk (1) mengetahui kelayakan bahan ajar IPS berbasis keragaman budaya batik jenogoroan; (2) mengetahui efektivitas bahan ajar IPS berbasis keragaman budaya batik jenogoroan untuk dapat meningkatkan berpikir kritis siswa di SMPN 2 Bojonegoro.

\section{METODE PENELITIAN}

Penelitian ini merupakan penelitian research and development, dengan menggunakan desain mengembangan Borg and Gall (Borg, W.R., Gall, M. D. 1993). Produk yang dikembangkan adalah modul keragaman budaya batik jenogoroan yang digunakan untuk siswa kelas VII-F di SMPN 2 Bojonegoro. Langkah-langkah dalam penelitian in meliputi tiga tahap yaitu: (1) studi pendahuluaan; (2) merancang produk; (3) uji coba produk. Sedangkan variabel dalam penelitian ini sebagai berikut (Sugiyono, 2011:30).
Tabel 1. Variabel Penelitian

\begin{tabular}{|c|c|c|}
\hline Tahap & Kegiatan & Variabel \\
\hline $\begin{array}{c}\text { Studi } \\
\text { pendahuluan }\end{array}$ & $\begin{array}{c}\text { Analisis } \\
\text { awal-akhir } \\
\\
\text { Analisis } \\
\text { karateristik } \\
\text { sisiwa }\end{array}$ & $\begin{array}{c}\text { Tingkat kualitas } \\
\text { bahan ajar di } \\
\text { SMPN } \\
\text { Bojonegoto } \\
\text { Kemampuan } \\
\text { siswa di sekolah }\end{array}$ \\
\hline $\begin{array}{l}\text { Validitas } \\
\text { dan revisi }\end{array}$ & $\begin{array}{l}\text { Validitas } \\
\text { dan revisi }\end{array}$ & $\begin{array}{c}\text { Kelayakan } \\
\text { modul }\end{array}$ \\
\hline $\begin{array}{l}\text { Uji coba dan } \\
\text { revisi }\end{array}$ & $\begin{array}{l}\text { Uji coba } \\
\text { dan revisi }\end{array}$ & $\begin{array}{l}\text { Kemampuan } \\
\text { berpikir kritis } \\
\text { siswa }\end{array}$ \\
\hline
\end{tabular}

Subyek uji coba dalam penelitian ini dilakukan pada siswa kelas VII-F di SMPN 2 Bojonegoro, sedangkan teknik dan instrument dalam penelitian dapat dilihat pada Tabel 2 di bawah ini (Iskandar, D. 2009:23).

Tabel 2. Teknik dan Instrumen Penelitian

\begin{tabular}{|c|c|c|}
\hline Variabel & $\begin{array}{c}\text { Teknik } \\
\text { Pengumpulan } \\
\text { Data }\end{array}$ & Instrumen \\
\hline $\begin{array}{l}\text { Kualitas } \\
\text { bahan ajar } \\
\text { siswa di } \\
\text { sekolah }\end{array}$ & observasi & $\begin{array}{c}\text { Lembar } \\
\text { observasi } \\
\text { kualitas } \\
\text { bahan ajar }\end{array}$ \\
\hline $\begin{array}{c}\text { Kemampuan } \\
\text { siswa di } \\
\text { sekolah }\end{array}$ & Tes & $\begin{array}{l}\text { Tes tulis } \\
\text { soal uraian }\end{array}$ \\
\hline $\begin{array}{c}\text { Kelayakan } \\
\text { modul }\end{array}$ & Validasi & $\begin{array}{c}\text { Lembar } \\
\text { validasi } \\
\text { modul }\end{array}$ \\
\hline $\begin{array}{c}\text { Kemampuan } \\
\text { berpikir } \\
\text { kritis siswa }\end{array}$ & Tes & $\begin{array}{c}\text { Tes tulis } \\
\text { soal uraian }\end{array}$ \\
\hline
\end{tabular}

Teknik pengumpulan data dalam penelitian ini yaitu: (1) observasi; (2) wawancara; dan (3) tes. Sedangkan teknik analisis data dalam penelitian ini dilakukan oleh peneliti semenjak awal pada setiap aspek kegiatan penelitian. Teknik analisis data dalam penelitian ini dapat dilihat pada Tabel 3 di bawah ini (Mulyana, Deddy. 2008: 20). 
Tabel 3. Teknik Analisis Data

\begin{tabular}{|c|l|}
\hline Variabel & Teknik Analisis Data \\
\hline $\begin{array}{c}\text { Kualitas bahan } \\
\text { ajar di sekolah }\end{array}$ & $\begin{array}{l}\text { Analisis kualitatif } \\
\text { deskritif }\end{array}$ \\
\hline $\begin{array}{c}\text { Kemampuan } \\
\text { siswa }\end{array}$ & $\begin{array}{l}\text { Analisis ketuntasan } \\
\text { klasikal } \\
\text { Analisis ketuntasan } \\
\text { individual }\end{array}$ \\
\hline $\begin{array}{c}\text { Kelayakan } \\
\text { modul }\end{array}$ & $\begin{array}{l}\text { Analisis kualitatif } \\
\text { deskritif }\end{array}$ \\
\hline $\begin{array}{c}\text { Kemampuan } \\
\text { berpikir kritis } \\
\text { siswa }\end{array}$ & $\begin{array}{l}\text { Analisis ketuntasan } \\
\text { klasikal } \\
\text { Analisis ketuntasan } \\
\text { individual } \\
\end{array}$ \\
& $\begin{array}{l}\text { Deskriptif kuantitatif } \\
\text { uji T }\end{array}$ \\
\hline
\end{tabular}

\section{HASIL DAN PEMBAHASAN}

Tahap pertama dalam penelitian ini adalah tahap studi pendahuluan. Pada tahap ini meliputi analisis kualitas bahan ajar di sekolah, analisis karakteristik siswa, dan analisis konsep. Pada analisis kualitas bahan ajar di sekolah dilakukan observasi menggunakan instrument lembar observasi.

Hasil observasi yang dilakukan peneliti di SMPN 2 Bojonegoro bahwa selama ini penyampaian materi pembelajaran kepada siswa bersifat transfer pengetahuan (transfer of knowledge) belum terpadu secara terintegrasi pada nilai dan keterampilan. Serta materi dan bahan ajar yang digunakan oleh guru hanya terfokus pada buku pegangan guru dan siswa, padahal di dalam buku siswa pada materi keragaman budaya minim pengetahuan dan tidak mencukupi dari segi kedalaman pengetahuan tentang keragaman budaya.

Sedangkan pada analisis karakteristik siswa dilakukan wawancara kepada guru matapelajaran untuk mengetahui karakteristik siswa, hasil wawancara menunjukkan bahwa siswa kelas VII-F memiliki tingkat kecerdasan rata-rata sedang, yang mana siswa kurang memiliki kemampuan berpikir kritis dalam kegiatan pembelajaran. Siswa cenderung hanya mendengarkan penjelasan dari guru, sehingga kurangnya proses berpikir kritis di dalam aktivitas belajar.

Selain itu dilihat pada hasil pre test yang peneliti lakukan yang mana sebagian siswa masih belum tuntas, serta kemampuan siswa dalam memecahkan masalah sangat rendah, terlihat saat siswa diberikan tugas yang berhubungan dengan penalaran dalam memecahkan masalah.

Sehingga menunjukkan bahwa kemampuan siswa dalam berpikir kritis sangat kurang. Pada analisis konsep dalam penelitian ini membandingkan adanya konsep-konsep pada buku siswa dengan konsep-konsep pada modul keragaman budaya batik jenogoroan yang dikembangkan.

Tahap kedua adalah tahap perancangan, yang meliputi merancang produk dan validasi dan revisi. Pada tahap merancang produk terdapat tiga langkah yaitu: 1) penyusunan tes; 2) pemilihan media yang sesuai dengan tujuan; 3) pemilihan format (BNSP, 2006).

Sedangkan pada tahap validasi, modul keragaman budaya batik jenogoroan dikembangkan dilakukan penilaian oleh para ahli untuk melihat validitas pembelajaran, isi, dan bahasa mencakup semua pengembangan. Hasil validasi ahli berupa koreksi, kritik dan saran yang digunakan sebagai dasar oleh peneliti untuk melakukan revisi dan penyempurnaan terhadap bahan ajar yang dikembangkan peneliti.

Berdasarkan hasil validasi dari para ahli menunjukkan bahwa rata-rata dari ketiga validator, menunjukkan bahwa ratarata dari komponen isi adalah 3,53 berkategori baik, rata-rata komponen penyajian 3,40 berkategori cukup baik dan rata-rata komponen bahasa 3,55 berkategori baik.

Hasil rata-rata ketiga komponen menunjukkan persentase sebesar 3,5 dengan kategori baik, yang artinya bahwa modul yang dikembangkan dapat digunakan dengan revisi kecil. Sehingga modul yang dikembangkan peneliti dikatakan layak dan berkategori cukup.

Tes yang disusun dalam penelitian ini dilakukan uji validitas dan reliabilitas, melalui hasil validitas dan reliabilitas soal diperoleh hasil validitas butir soal berpikir kritis, dari 6 soal yang dibuat peneliti menunjukkan valid yaitu pada butir soal 1 $(0,613), 2(0,501), 3(0,477), 4(0,624), 5$ $(0,530)$, dan $6(0,542)$ karena $r$ hitung $>$ dari 
r tabel/kritis (0,355), artinya ke-6 soal tersebut digunakan dalam penelitian. bahwa hasil reliabilitas butir soal berpikir kritis nomor 1, 2, 3, 4, 5, dan 6 bahwa jumlah dari skor alpha crobach di atas $r$ tabel/kritis, yaitu 0,514>0,355. Sehingga butir soal yang telah disusun peneliti menujukkan reliabel dengan kriteria sedang/cukup.

Tahap ketiga adalah tahap uji coba, pada tahap ini digunakan untuk mengetahui tingkat kemampuaan berpikir kritis siswa. Tahap uji coba merupakan tahan bahan ajar yang dikembangkan peneliti diuji cobakan di SMPN 2 Bojonegoro untuk memperoleh data berpikir kritis siswa melalui uji pretest dan posttest.

Berdasarkan hasil uji pre test dan post test dapat digambarkan bahwa tingkat Kemampuan berpikir kritis siswa kelas VIIF SMPN 2 Bojonegoro menunjukkan peningkatan pada uji pre test pada uji post test. Hasil nilai pre test dan post test dapat dilihat pada Tabel 4 di bawah ini.

Tabel 4. Hasil Pre Test dan Post Test

\begin{tabular}{|c|c|c|c|c|c|c|}
\hline No & Nama & Pre & Kriteria & Post & Kriteria & Keterangan \\
\hline 1 & Adinda Hapsari Casar Riani & $\frac{1 \text { est }}{66}$ & TT & $\frac{1}{75}$ & $\mathrm{~T}$ & Meninglkat \\
\hline & Afrellia Zalffa Putri & 61 & TT & 75 & T & \\
\hline 3 & Annisa Andra Azifa & 66 & TT & 79 & & Meningkat \\
\hline 4 & Annisa Normasari & 82 & T & 86 & $\mathrm{~T}$ & Meningkat \\
\hline 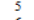 & Aulya Nur Sofiyah & 75 & $\mathrm{~T}$ & 78 & $\mathrm{~T}$ & Meningkat \\
\hline & $\begin{array}{l}\text { Bagas Yudis Tama } \\
\text { Bista }\end{array}$ & 列 80 & $\mathrm{~T}_{\mathrm{T}}$ & 㶾 & & Meningkat \\
\hline 8 & CantikA Arivanto & sio & & 10 & & 1etapp \\
\hline & olifatur $A z z i z i$ Rochim R & & TT & 79 & & Meningkat \\
\hline 10 & Dewi Okta Fantistiyana & 74 & TT & & $\mathrm{T}$ & Meningkat \\
\hline & Dinda Nellyanza Putri & 82 & & 85 & & $\begin{array}{l}\text { Meningkat } \\
\text { Mather }\end{array}$ \\
\hline 12 & Diva Nur Laili Rahmmawati & 82 & T & 89 & $\mathrm{~T}$ & Meningkat \\
\hline 13 & Eko Sriono Adi & 76 & T & 82 & $\mathrm{~T}$ & Meningkat \\
\hline & Ervin Nur Fatqur Roji & 69 & & & & Meningkat \\
\hline & Ferry Eko Naryanto & 56 & IT & 75 & $T_{T}^{T}$ & Meningkat \\
\hline &  & & TT & 75 & T & $\begin{array}{l}\text { Meningigkat } \\
\text { Meningkat }\end{array}$ \\
\hline & Lukmanul Hakim & 79 & $\mathrm{~T}$ & 84 & $\mathrm{~T}_{\mathrm{T}}$ & $\begin{array}{l}\text { Meningkat } \\
\text { Mengat }\end{array}$ \\
\hline & M. Dimas Aviv Fahreza & 73 & $\mathrm{~T}$ & 80 & $\mathrm{~T}$ & $\begin{array}{l}\text { Meningigkat } \\
\text { Meninglat }\end{array}$ \\
\hline 20 & Mafrisstus Nur Hayya Faizah & 66 & TT & 75 & T & Meningkat \\
\hline 21 & Moch. AinurRozilk & 84 & T & 92 & T & Meningkat \\
\hline & Moch.Arifuddin Muralkaz & 75 & $\mathrm{~T}_{\mathrm{T}}$ & ${ }^{80}$ & ${ }^{\mathrm{T}}$ & Meningkat \\
\hline & 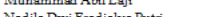 & & 11 & 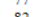 & & Meninglat \\
\hline & 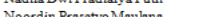 & & & & & Meningestat \\
\hline & Kusuma & 79 & & 82 & & Meningket \\
\hline & Sititi Alfians Dzakia & 79 & $\mathrm{~T}$ & 年 & -1 & Meningkat \\
\hline 28 & Aditya Ramadhan & 50 & TT & 75 & T & Meningkat \\
\hline & Wanda Dwi Febrianti & & T & 83 & & Meningkat \\
\hline \multirow{3}{*}{$\begin{array}{l}30 \\
31\end{array}$} & Yuda Satya Prakosa & 76 & $\mathrm{I}$ & 80 & 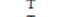 & Meningkat \\
\hline & $\begin{array}{l}\text { Yuvrrill } 2 \\
\text { Jumblah }\end{array}$ & 70 & & $7 / 7$ & & $\begin{array}{l}\text { Meningkat } \\
\text { Meningleat }\end{array}$ \\
\hline & Skor Rata-Rata & 72,13 & & 80,35 & & Meningkat \\
\hline
\end{tabular}

\section{Kelayakan Bahan Ajar IPS Berbasis} Keragaman Budaya Batik Jenogoroan

Kelayakan bahan ajar dalam penelitian ini berbentuk modul yang digunakan dalam pembelajaran. Hasil analisis proses validasi yang dilakukan dalam penelitian ini menunjukkan bahwa bahan ajar berupa modul yang dikembangkan secara rata-rata memperoleh kategori cukup baik atau cukup layak untuk digunakan.

Hasil validasi dari ketiga validator untuk modul menunjukkan skor rata-rata dari segi kelayakan isi sebesar 3,53 kategori baik/layak, skor rata-rata dari segi kelayakan kebahasan sebesar 3,40 kategori cukup baik/layak, dan skor rata-rata dari segi kelayakan penyajian sebesar 3,55 kategori baik/layak, sedangkan jumlah keseluruhan skor rata-rata dari ketiga komponen sebesar 3,5 menunjukkan kategori baik/layak yang artinya modul layak dan dapat digunakan dengan sedikit revisi. Hasil skor validasi dapat dilihat pada gambar diagram di bawah ini sebagai berikut.

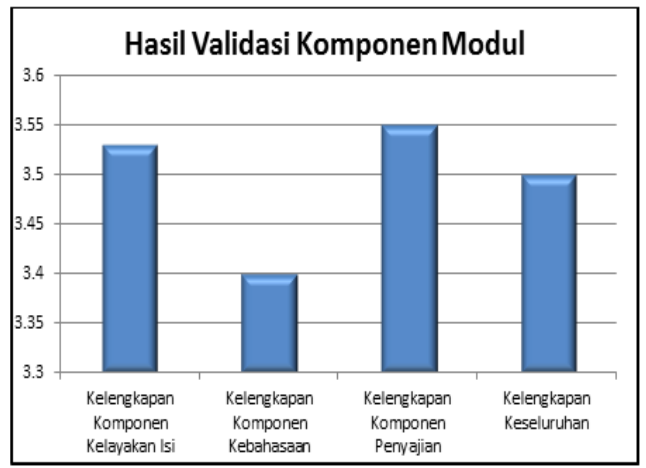

Gambar 1. Hasil Validasi Modul

\section{Tingkat Efektivitas Modul IPS Berbasis Keragaman Budaya Batik Jenogoroan untuk Meningkatkan Kemampuan Berpikir Kritis Siswa}

Berdasarkan hasil penelitian dalam pencapaian tingkat keefektifan kemampuan berpikir kritis siswa kelas VII-F di SMPN 2 Bojonegoro, sebelum dan sesudah menggunakan modul keragaman budaya batik jenogoroan melalui uji pre test dan post test menunjukkan peningkatan yang baik, seperti pada gambar diagram di bawah ini.

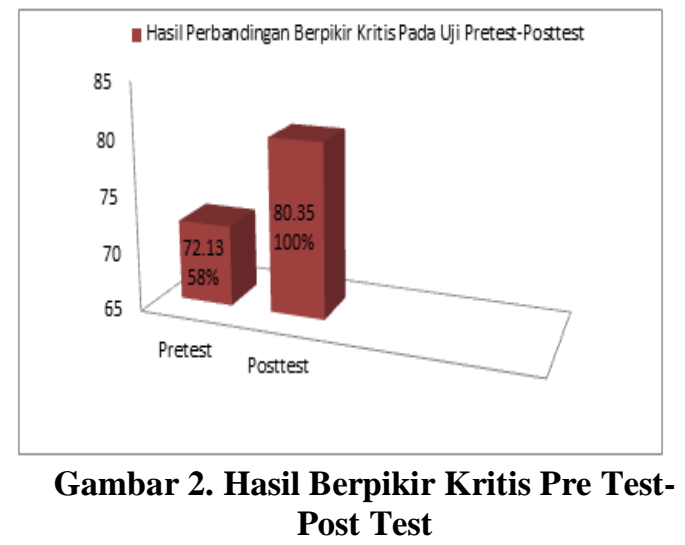


Rata-rata pada uji pre test sebesar 72.13 sedangkan pada uji post test meningkat sebesar 80.35. terjadi peningkatan sebesar 8,22 dari pre test menunju post test. Hasil tersebut menunjukkan bahwa kemampuan berpikir kritis mengalami peningkatan pada sebelum dan sesudah diberikan modul keragaman budaya batik jenogoroan.

Tabel di atas menunjukkan bahwa adanya perbedaan dari hasil pretest dan posttest, sehingga modul keragaman budaya batik jenogoroan dapat meningkatkan kemampuan berpikir kritis siswa, selain itu hasil diperkuat dengan adanya perhitungan menggunakan SPSS 15,0 yang menunjukkan hasil bahwa nilai T-hitung sebesar -8.894, sedangkan T-tabel pada penelitian ini yaitu df 30 dengan taraf significant 5\% maka diperoleh T-tabel sebesar 1.697.

Dengan demikian, dapat disimpulkan bahwa T-hitung $>$ T-tabel $\quad(-8.894>1.697)$, sehingga menunjukkan $\mathrm{H} 1$ diterima $\mathrm{H}_{0}$ ditolak artinya ada perbedaan antara sebelum dan sesudah dilaksanakan pembelajaran IPS dengan menggunakan modul keragaman budaya batik jenogoroan pada siswa kelas VII-F di SMPN 2 Bojonegoro. Pada kolom Sig (2-tailed) juga menunjukkan bahwa nilai $\mathrm{p}$-value $<$ level of significant $5 \%(0,000<0,05)$, yang artinya diterima Ha menunjukkan bahwa adanya hubungan yang significant terhadap peningkatan kemampuan berpikir kritis siswa antara uji pre test dan post test.

Adanya hasil peningkatan berpikir kritis di atas menunjukkan bahwa pengembangan modul keragaman budaya batik jenogoroan sangat efektif digunakan dalam pembelajaran IPS. Hal tersebut sesuai dengan teori kontruktivisme, yang mana pentingnya siswa membangun sendiri pengetahuan mereka lewat keterlibatan aktif proses belajar mengajar. Pada pembelajaran kontruktivisme memusatkan perhatian kepada berpikir atau proses mental anak tidak sekedar pada hasilnya tetapi mengutamakan peran siswa dalam berinisiatif sendiri untuk terlibat dalam pembelajaran (Fiszer,2009:75).
Pengembangan modul keragaman budaya batik jenogoroan sangat dibutuhkan siswa dalam pembelajaran, selain untuk menarik minat siswa juga untuk efektif dapat meningkatkan kemampuan berpikir kritis siswa, karena interaksi dari hasil pembelajaran yang berorientasi pada lingkungan sosial budaya akan lebih berkembang (Baharuddin, 2009:124).

Seperti yang dikatakan Piaget dan Vygotsky yang menekankan pada pentingnya lingkungan sosial dalam belajar dengan menyatakan bahwa integrasi kemampuan dalam belajar kelompok akan dapat meningkatkan pengubahan secara konseptual (Baharuddin, 2009:117). Seperti yang dikatakan Vygotsky bahwa dalam pembelajaran melibatkan 2 elemen penting salah satunya berkaitan erat dengan lingkungan sosial budaya (Baharuddin, 2009:124).

Adanya teori dari Piaget dan Vygotsky menunjukkan bahwa modul keragaman budaya batik jenogoroan yang dikembangkan peneliti efektif dapat meningkatkan kemampuan siswa dalam berpikir kritis, belajar berdasarkan apa yang ada di lingkungan sekitar siswa akan lebih menarik siswa dalam menggali pengetahuan yang sudah mereka ketahui ((Munadi, 2013:25).

Pengetahuan yang sudah ada akan membuat siswa berpikir kritis untuk mengaitkan apa yang diketahui dengan pengetahuan yang baru dari ada pembelajaran dengan modul berbasis keragaman budaya batik jenogoroan.

Seperti yang dikemukakan oleh Jean Piaget dan Vygotsky bahwa perubahan kognitif kearah perkembangan terjadi ketika konsep-konsep yang sebelumnya sudah ada mulai bergeser karena ada sebuah informasi baru yang diterima melalui proses ketidakseimbangan (Baharuddin, 2009:117).

\section{SIMPULAN}

Berdasarkan hasil penelitian yang sudah dibahas di atas, maka dapat ditarik kesimpulan sebagai berikut (1) Kelayakan pengembangan bahan ajar IPS dalam bentuk modul berbasis keragaman budaya 
batik jenogoroan untuk meningkatkan berpikir kritis siswa kelas VII-F di SMPN 2 Bojonegoro layak digunakan melalui uji validasi para ahli. Hasil validasi modul keragaman budaya batik jenogoroan dilakukan oleh tiga validator; (2) Kelayakan modul dilihat dari 3 komponen yaitu komponen isi, penyajian, dan kebahasaan. Hasil skor rata-rata ketiga komponen dari kedua validator tersebut sebesar 3,53, sedangkan skor rata-rata komponen isi sebesar 3,40, skor rata-rata komponen penyajian sebesar 3,55, dan skor rata-rata komponen kebahasaan sebesar 3,5; (3) Skor rata-rata tersebut menunjukkan kategori baik/layak yang artinya modul berbasis keragaman budaya batik jenogoroan dapat digunakan dengan sedikit revisi.

Efektivitas bahan ajar IPS dalam bentuk modul berbasis keragaman budaya batik jenogoroan untuk meningkatkan berpikir kritis siswa menunjukkan bahwa modul berbasis keragaman budaya batik jenogoroan efektif dapat meningkatkan berpikir kritis siswa kelas VII-F di SMPN 2 Bojonegoro.

DAFTAR PUSTAKA.

Ahmadi, Khoiru, I., Amri, S. 2011. Metode pembelajaran ips terpadu Analisis kritis tentang metode, strategi, evaluasi, dan media pembelajaran bidang studi sejarah, geografi, ekonomi, sosiologi, antropologi dan isu pembelajaran ips terpadu. Jakarta: PT. Prestasi Pustakarya,.

Arikunto. 2010. Prosedur penelitian: Suatu pendekatan praktik. (edisi revisi). Jakarta: Rineka Cipta.

Bachman, E. 2005. Metode belajar berpikir kritis dan inovatif, Jakarta: Prestasi Pustaka.

Baharuddin., Wahyuni Nur Esa. 2009. Teori belajar \& pembelajara, Yogyakarta: Ar Ruzz Media Group.

Borg, W.R., Gall, M. D. 1993. Educational research: An introduction, Boston, New York, and London: Pearson Education.
Hal ini dapat dilihat berdasarkan hasil tes dari pre test dan post test yang mengalami peningkatan atau kenaikan kemampuan siswa rata-rata dari 72,13 meningkat menjadi 80,35, terjadi peningkatan sebesar 8,22 dari pre test menuju post test, yang artinya berdasarkan hasil tersebut menunjukkan bahwa modul keragaman budaya batik jenogoroan efektif digunakan untuk meningkatkan kemampuan berpikir kritis siswa.

Sedangkan saran yang bisa peneliti berikan demi terwujudnya pembelajaran di kelas, bahwa guru IPS hendaknya mengembangkan bahan ajar dalam setiap pembelajaran, khususnya yang berbasis lingkungan.

Karena dengan adanya pengembangan bahan ajar tersebut guru dapat menyiapkan sumber belajar yang sesuai dengan karakteristik siswa, untuk dapat membuat siswa semangat dan aktif dalam pembelajaran sehingga tidak membuat bosan serta dapat meningkatkan kemampuan berpikir kritis siswa.

BNSP. 2006. Standar penilaian, Jakarta: Departemen Pendidikan Nasional,

Dewa Gede Alit Rai Bawa. 2014. Pengembangan bahan ajar ips berorientasi ips terpadu untuk siswa smp kelas vii, E-Journal pendidikan Ganesha volume 4,.

Dikmenjur. 2004. Kerangka penulisan modul, Jakarta: Dikmenjur, Depdiknas.

Fisher, Alec. 2009. Berpikir kritis: Sebuah pengantar, Jakarta: Erlangga.

Iskandar, D. 2009. Metodologi penelitian pendidikan dan sosial (kuantitatif dan kualitatif), Jakarta: Gaung Persada Press.

Munadi, Yudhi. 2013. Media pembelajaran (sebuah pendekatan baru), Jakarta: Referensi (GP Press Group).

Munandar, Utami. 2009. Berbagai masalah pendekatan dalam proses belajar mengajar, Jakarta: Bina Aksara.

Mulyana, Deddy. 2008. Metodologi penelitian kualitatif: Paradigma baru ilmu komunikasi dan ilmu sosial 
lainnya, Bandung: PT. Remaja Rosdakarya.

Mulyani, Siti. 2013. Pengembangan model bahan ajar berbasis potensi daerah untuk menunjang pembelajaran bahasa jawa. Jurnal kependidikan, vol 43, nor 1.

Mulyasa, 2008. Standar kompetensi dan sertifikasi guru, Bandung: Remaja Rosdakarya.

Pannen, I aulina, 2001. Kontrukvisme dalam pembelajaran direktorat jendral pendidikan tinggi departemen pendidikan nasional. Jakarta.

Praswoto, Andi. 2002. Panduan kreativitas membuat bahan ajar inovatif, Yogyakarta: Diva Press.
Rachmah, Huriah. 2014. Pengembangan profesi pendidikan ips, Bandung: Alfabeta.

Sariyatun. 2012. Pengembangan model pembelajaran dengan nilai-nilai budaya seni batik klasik untuk meningkatkan identitas diri siswa. Journal International of history education. Vol. XII, No 2.

Sugiyono. 2011. Pendekatan kuantitatif, kualitatif dan $r \& d$. Bandung: Alfabeta.

Trianto. 2007. Model pembelajaran terpadu dalam teori dan praktek, Jakarta: Perpustakaan Nasional.

Trianto. 2011. Model-model pembelajaran inovatif berorientasi konstruktivistik, Jakarta: Prestasi Pustaka. 